\title{
Growth trends in three bivalve species indicate climate forcing on the benthic ecosystem in the southeastern North Sea
}

\author{
Rob Witbaard*, Gerard C. A. Duineveld, Teresa Amaro, Magda J. N. Bergman
}

Royal Netherlands Institute for Sea Research, PO Box 59, 1790 AB Den Burg, Texel, The Netherlands

\begin{abstract}
Internal growth lines in shells of 3 suspension-feeding bivalves (Arctica islandica, Mya truncata and Chamelea striatula) from the SE North Sea were analysed in search of common interannual variations of their growth rate. The high similarity (69 to $80 \%$ ) between the growth records in the 3 species suggests that a large-scale (climatic) factor is responsible for an important part of the variation in annual shell growth. The common trend extracted from the individual growth records was correlated with monthly data on phytocolour, NAO index, temperature and wind. The strength and sign of the effect of the last 3 factors varied seasonally. Effects of wind strength and direction were analysed in detail, as in situ measurements showed that wind speeds $>10 \mathrm{~m} \mathrm{~s}^{-1}$ (Beaufort 6) cause resuspension of fine sediment at the site where the bivalves were collected. Resuspended sediment causes a drop in the quality of food for suspension feeders. During the bivalve growing season, northwesterly to easterly winds tended to depress growth, whereas winds with a westerly component mainly had a positive effect. Strong winds from a WNW direction in May, however, had a negative effect and could explain the highest proportion of variance in the common growth trend; WNW winds have a long fetch at the study area and generate (high) long waves, facilitating resuspension of fine sediment at relatively low wind speeds.
\end{abstract}

KEY WORDS: Bivalves $\cdot$ Shell growth $\cdot$ North Sea $\cdot$ Climate forcing $\cdot$ Wind

\section{INTRODUCTION}

Recent studies have demonstrated the occurrence of Atlantic-wide temporal variations in the abundances of zoo- and phytoplankton (Reid et al. 1998, 2001), and Aebischer et al. (1990) showed that parallel trends occur across different trophic levels. These results indicate that large-scale oceanic and climatic processes play a major role in the variability of ecosystem structure and functioning in the North Atlantic. The common forcing factor proposed to explain these parallel trends is the North Atlantic Oscillation (NAO) (Hurrell 1995, Ottersen et al. 2001, Reid et al. 2001, Drinkwater et al. 2003). The NAO index is the parameterisation of the pressure difference between Iceland and the Azores, and it largely determines wind, temperature and precipitation regimes over NW Europe.
This affects water circulation and stratification processes in the North Sea.

Due to the close coupling between climate and hydrography, attention on NAO-related changes has focussed on abundance and distribution of planktonic organisms (e.g. algae, copepods, chaetognaths; Fromentin \& Planque 1996, Irigoien et al. 2000). Fisheries interests have further contributed to this focus (Corten 2001, Beaugrand et al. 2003). A growing number of studies have shown that the variability in benthic communities is also linked to the NAO (e.g. Kröncke et al. 1998, Hagberg \& Tunberg 2000). This is not surprising as benthic organisms rely on organic matter derived from the pelagic system, and thus on pelagic productivity. Moreover, climate driven hydrography (currents, stratification) can directly affect conditions for benthic organisms as well. The effects of the NAO 


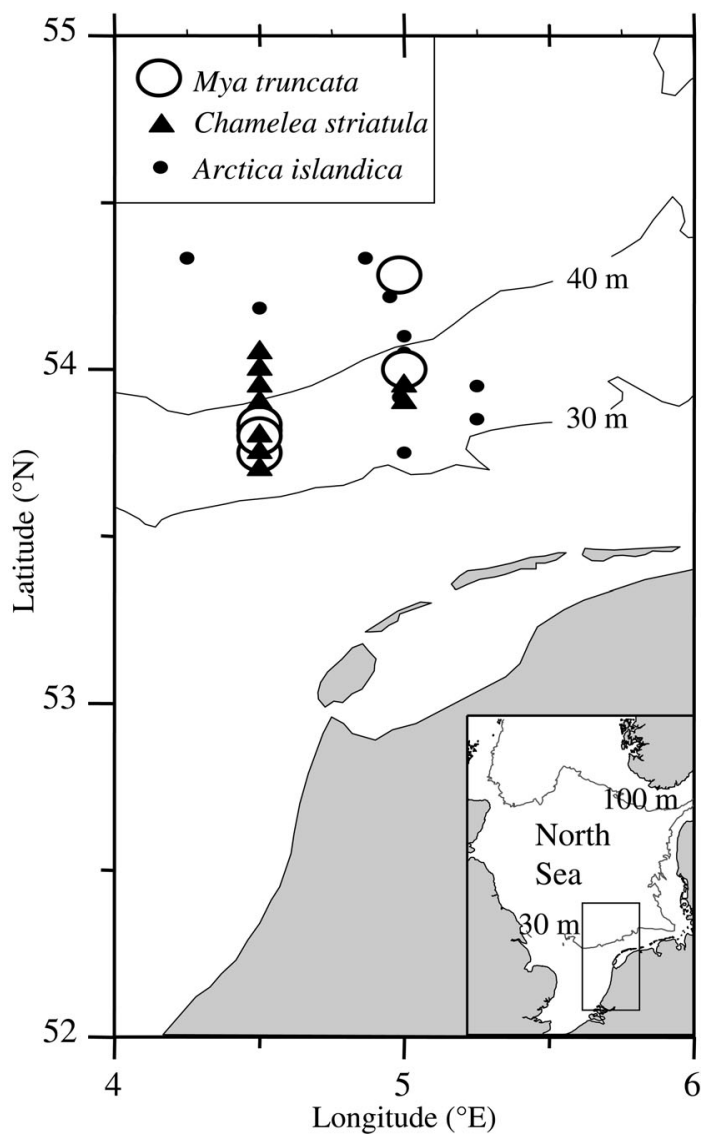

Fig. 1. Sampling site of the bivalves used in this study, SE North Sea

differ between geographical areas (Ottersen et al. 2001), because they depend on ecosystem complexity and on the pathways by which the ecosystem is controlled. Within a limited geographical area, however, ecosystem forcing by climate or hydrography should result in congruent trends among biotic components occupying a similar ecological niche.

Although the NAO has been associated with changes in species composition and biomass of benthic communities (Wieking \& Kröncke 2001), there are also more subtle effects of climatic variability, e.g. on growth rates, as evidenced by the analysis of the skeletal growth records in corals and bivalves. The correlations between climate and skeletal growth found so far pertain to selected single species with a suitable growth record. However, in order to verify that climatic variations have community-wide implications, these analyses should be done on several species from 1 community.

The primary objective of the present study was to determine whether such parallel growth patterns exist among 3 filter-feeding bivalve species (Arctica islandica, Chamelea striatula and Mya truncata) living at the Frisian Front in the SE North Sea (Fig. 1). Our second objective was to find the underlying mechanism, if a parallel growth pattern was found. External (climatic) factors such as bottom water temperature and primary production affect the growth of filterfeeding bivalves (e.g. Dekker \& Beukema 1999, Beukema et al. 2002). Food quality is probably another important factor that determines growth. Circumstantial and experimental evidence (Grant et al. 1997, Cranford et al. 1998, Witbaard et al. 2001) suggests that resuspension of fine sediment causes a decline in food quality, which leads to depressed shell growth in bivalves. Resuspension of fine sediments in the shallow SE North Sea is caused by a combination of tidal and wave currents. The latter are strongly controlled by the wind. We therefore selected wind speed and direction as additional explanatory variables for shell growth. To validate the presumed link between wind and resuspension, we used the data obtained by a benthic lander deployed in our study area in the summer of 2001.

\section{MATERIALS AND METHODS}

\subsection{Study site and sampling}

Live specimens of the filter-feeding bivalves Arctica islandica, Chamelea striatula and Mya truncata were collected in and just north of the Frisian Front in the southern sector of the Oyster Grounds (SE North Sea) (Fig. 1). Water depth in this area ranges from $30 \mathrm{~m}$ in the south to $45 \mathrm{~m}$ in the north. With the gradual deepening towards the north, the maximum tidal velocity decreases from 1.8 to 0.7 knots, resulting in a south to north transition from coarse to fine sediments (Creutzberg \& Postma 1979, Creutzberg et al. 1984); the silt fraction ranges from 10 to $>20 \%$. A tidal front at the southern border of the area separates the tidally mixed water mass in the south from the summerstratified water that overlies the central Oyster Grounds, and a persistent chl a maximum occurs in the frontal zone (Creutzberg 1985). The bottom water temperature ranges from approximately $4^{\circ} \mathrm{C}$ in early spring to a maximum of $16^{\circ} \mathrm{C}$ at the end of summer.

All 3 bivalve species are suspension feeders that live burrowed in the sediment. Chamelea striatula is regarded as a lusitanian species, while Arctica islandica and Mya truncata are regarded as boreal and boreal-arctic species, respectively. The latter 2 species reach their southern distribution limits in the North Sea at the Frisian Front (Amaro et al. 2003, Witbaard \& Bergman 2003). For C. striatula the Oyster Grounds lies in the northern part of its distribution range (Witbaard et al. 2001). There has been some confusion about the taxonomy of C. striatula. Previously, some 
authors regarded C. striatula as one of the 2 formae of C. gallina.

The specimens were collected with a Triple-D dredge (Bergman \& van Santbrink 1994) during a series of cruises in 1998, 1999 and 2000. The sampling area is enclosed by the corners $53^{\circ} 30^{\prime} \mathrm{N}, 4^{\circ} 15^{\prime} \mathrm{E}$, and $54^{\circ} 30^{\prime} \mathrm{N}, 5^{\circ} 30^{\prime} \mathrm{E}$, about 30 nautical miles north of the island of Texel (Fig. 1). Specimens of all 3 species were frozen for transport and storage. In the laboratory, their soft tissue was removed. In total, 29 specimens of Mya truncata, 21 specimens of Arctica islandica, and 27 specimens of Chamelea striatula were used for this study.

\subsection{Shell chronologies}

The marked growth banding in shells of Arctica islandica and Chamelea striatula is caused by the strong seasonal variation in temperature and production, and has an annual pattern (Ramon \& Richardson 1992, Witbaard et al. 1994). Based on the results published for the closely related species Mya arenaria (MacDonald \& Thomas 1980, Brousseau \& Baglivo 1987) we assumed that growth bands in Mya truncata are formed annually as well, although this periodicity has not been verified by us. On the basis of band counts, the maximum ages found for $M$. truncata and C. striatula are 27 and $21 \mathrm{yr}$, respectively (Witbaard et al. 2001, Amaro et al. 2003). The maximum age of $A$. islandica is estimated to surpass $200 \mathrm{yr}$ (Jones 1983), although specimens with such longevity have never been found in the SE North Sea.

We made acetate peel replicas (Ropes 1985) of the resin embedded and etched shell cross sections. The increment widths were measured with a compound Zeiss microscope from the hinge band portion of the shell (for details see Witbaard 1997). Because all specimens were caught alive, it was assumed that the year in which the outermost increment was deposited corresponded to the year of sampling. By counting backwards, each measured growth increment could be assigned to a particular calendar year. For each cross section this resulted in an absolutely dated time series of hinge band increment widths.

All specimens showed an ontogenetic trend of decreasing growth ring widths with age. We removed this trend by fitting a 7 to $15 \mathrm{yr}$ cubic spline. This detrending procedure produced for each shell a time index series that for each year reflects whether growth was below or above the expected rate. For each species, the dating of the individual time series of growth variations was checked by cross-dating them with the dendrochronology computer programs COFECHA (Holmes 1983, Grissino-Mayer 2001) and
PAST (www.sciem.com/). For the final alignment of the growth records the Percent of Common Variation $(\mathrm{PCV}=$ sign test $)$ and the correlation coefficient were used to assess the quality of the alignment. With these detrended and cross-dated time-series a speciesspecific standard chronology was constructed by averaging the individual standardized curves.

\subsection{Environmental variables}

A principal component analysis (PCA) was used to extract the common trend from the 3 species-specific average chronologies of growth rate variations. This common trend, being the first component extracted, was related to environmental variables by means of response function analysis (Fritts et al. 1971, Fritts \& Shashkin 1995) and stepwise multiple regression in SYSTAT v. 10. In this process, the standardised yearly common variations in shell growth are linked to monthly climatic variables. As part of the analyses, a response function is calculated from the principal components of the monthly environmental variables. This resolves the problem of co-linearities of the latter variables (Fritts et al. 1991).

The environmental variables used for these analyses were Continous Plankton Recorder (CPR) phytocolour, air temperature, bottom water temperature, and wind strength and direction. CPR phytocolour for standard area D1 (SAHFOS, Plymouth, UK; http:// 192.171.163.165/standard_areas.htm) was used as a proxy for phytoplankton standing stock and primary production in the area. The wind data refer to potential wind speed derived from wind measurements made by the Royal Netherlands Meteorological Institute (KNMI) at the offshore platform K13 $\left(53^{\circ} 22^{\prime} \mathrm{N}, 3^{\circ} 22^{\prime} \mathrm{E}\right)$ located SW of the area of investigation. Potential wind speed is the measured speed recalculated to the wind speed at a standardised height and roughness length to adjust for topographical differences at the location of measurement (see www.knmi.nl/samenw/hydra/). Since wind and temperature are both related to the NAO index, this index was tested as a common forcing factor representing large-scale climatic and oceanic processes.

For the response function analysis we applied a 4 mo time lag between forcing factor and shell growth. This is based on the observed relationship of seasonal cycles of primary production and temperature with seasonal shell deposition, especially in Arctica islandica. Data from the East coast of the USA (Jones 1980) plus empirical evidence from the northern North Sea (Witbaard et al. 2003) showed that A. islandica terminates growth at the end of summer, and then starts depositing a new increment. The carbonate 
deposited between 2 growth stops thus partly represents the autumn months of the year preceding the one in which the increment was terminated by the second growth stop. An increment thus actually covers the approximate period August to July, rather than January to December.

\subsection{Field observations of current speed and resuspension}

In 2001, a tripod built by NIOZ and equipped with a current meter (Falmouth Scientific Instruments, 3dACM) and an optical backscatter sensor (OBS) (Seapoint) was moored near the collection site at $53^{\circ} 42^{\prime} \mathrm{N}$, $4^{\circ} 30^{\prime} \mathrm{E}$. Both instruments were mounted $0.5 \mathrm{~m}$ above the sediment. A tilt sensor in the current meter recorded movement of the tripod. Two series of measurements were made (29 May to 6 June, and from 24 July to 12 September).

\section{RESULTS}

\subsection{Relationship between wind speed and sediment resuspension}

The tripod with OBS and current meters was deployed twice, in late spring and late summer 2001. Due to a technical failure, we obtained no current meter data for the first period. In Fig. 2 we have combined the records of the current meter and OBS with the wind speed for the period 24 July to 12 September. Spring tides in this period fell on 24 July, 6 and 21 August and 4 September. There are 3 major turbidity peaks. The start of each peak in backscatter (vertical dashed lines in Fig. 2) coincides with enhanced current and wind speed. In the case of the first and second peak on 8 August and 5 September, currents related to the spring tide may have enhanced the wind (wave) effect. The third turbidity peak (8 September) is due to wind alone. Spring tides alone do not evoke resuspen-
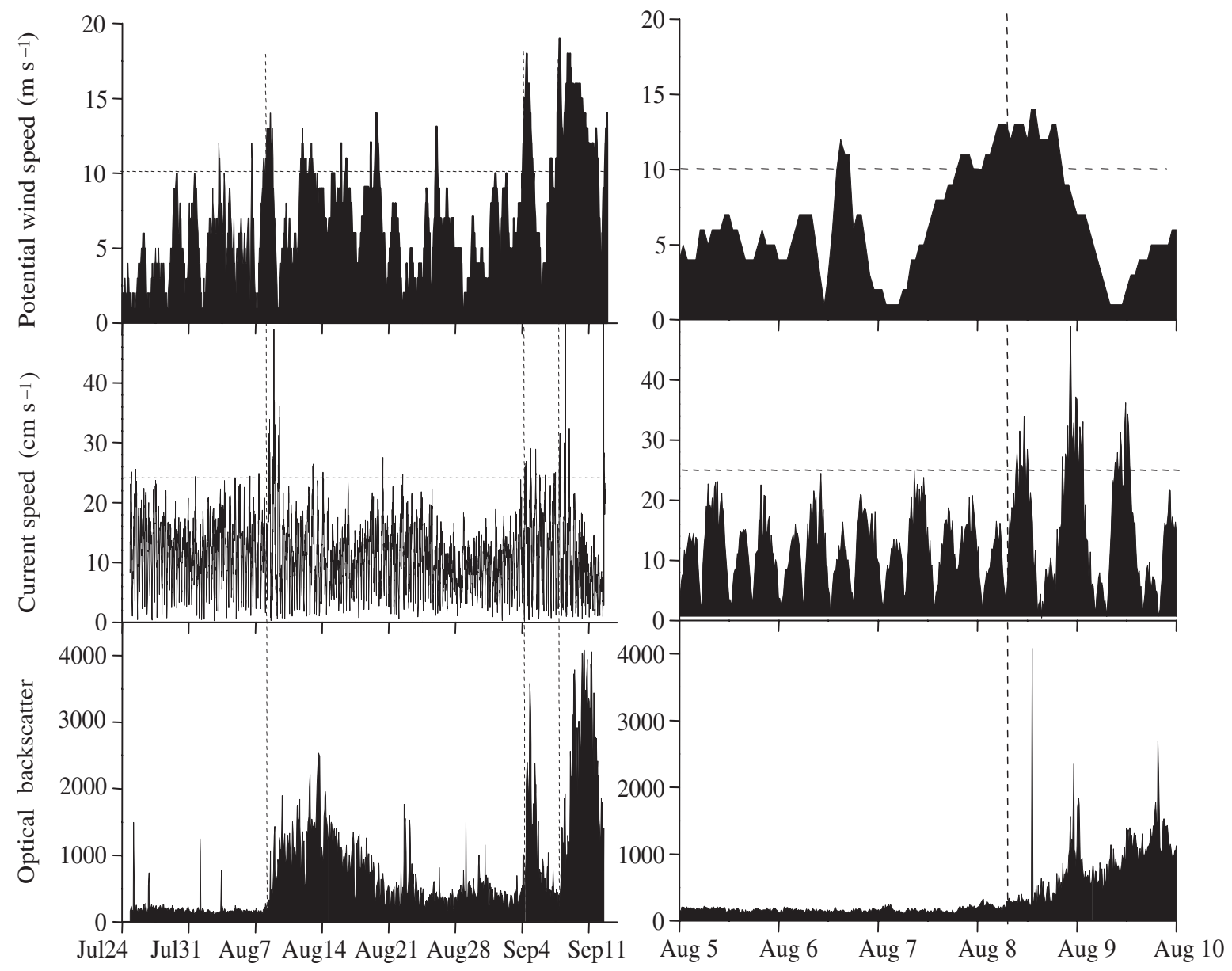

Fig. 2. Potential wind speed at $10 \mathrm{~m}$ above sea surface, bottom current speed and turbidity (measured as optical backscatter at $0.5 \mathrm{~m}$ above the seabed). Left panels: recordings over the entire period of deployment. Right panels: recordings over the period 5 to 10 August 2001 
sion, as can be seen around 24 July. This observation is in agreement with Williams et al. (1998).

Current speeds over $0.25 \mathrm{~m} \mathrm{~s}^{-1}$ at $0.5 \mathrm{~m}$ height above the bottom resuspend the sediment (Fig. 2). The empirical relation between turbidity, and current (wave and tidal) and wind velocities is illustrated in detail in the right-hand panels for the period 5 to 10 August. This interval began with a period of 2 quiet days with variable (S to SW) winds followed by a $24 \mathrm{~h}$ period with a strong breeze $\left(10 \mathrm{~m} \mathrm{~s}^{-1}\right.$, Beaufort 6$)$. After approximately $12 \mathrm{~h}$ of a strong SW breeze the maximum flood current speed in NE direction increased to $>0.25 \mathrm{~m} \mathrm{~s}^{-1}$, giving rise to an increase in turbidity. A similar series of events can be seen for the peaks on 4 and 11 September. On the basis of these observations, we took $10 \mathrm{~m} \mathrm{~s}^{-1}$ (Beaufort 6) as the minimum wind speed required for resuspension of Frisian Front sediment.

\subsection{Analysis of growth variations}

Details of the bivalves used are given in Table 1. Age was estimated on the basis of the number of growth bands. The overview of ages in Table 1, however, does not reflect the actual age composition of the field population, since we selected for the larger shell sizes, i.e. older specimens. The mean correlation and percent similarity in Table 1 gives the average level of similarity between individual growth index series and the population mean after exclusion of that particular individual. Due to the relative short lengths of the time series, the average level of correlation is just below the threshold normally accepted to incorporate a specimen in the average curve. The PCV is often extremely high and is significant at $\mathrm{p}=0.05$. Maximum correlation coefficients were as high as 0.89 for Chamelea striatula, 0.82 for Mya truncata and 0.75 for Arctica islandica.

Distinct growth rate variations can be seen over the last 20 to $40 \mathrm{yr}$ in the growth records of all 3 bivalve

Table 1. Mya truncata, Arctica islandica, Chamelea striatula. Biometric data of the samples. Height and age data (mean and range) do not represent the field populations, since we selected for shell size and age. Correlation (r) and percent of common variation (PCV) (mean $\pm \mathrm{SD}$ ) indicate how well the individual time index series fits the mean curve. PCV is a nonparametric parameter which only takes the similarity of the growth rate change into account

\begin{tabular}{|c|c|c|c|c|}
\hline & $\begin{array}{l}\text { Shell height } \\
\quad(\mathrm{mm})\end{array}$ & $\begin{array}{l}\text { Age } \\
(\mathrm{yr})\end{array}$ & $\mathrm{r}$ & $\begin{array}{l}\text { PCV } \\
(\%)\end{array}$ \\
\hline M. truncata & $51(43-56)$ & $18(14-27)$ & $0.58 \pm 0.1$ & $74.2 \pm 8.8$ \\
\hline A. islandica & $61(50-74)$ & $24(12-54)$ & $0.51 \pm 0.2$ & $73.3 \pm 10.9$ \\
\hline C. striatula & $23(18-28)$ & $14(10-19)$ & $0.55 \pm 0.2$ & $72.8 \pm 7.4$ \\
\hline
\end{tabular}

species (Fig. 3A-C). The patterns of growth rate variations show a great similarity between species (Fig. 3D). A sign-test (PCV) that tests for similarity in growth rate changes without accounting for the magnitudes of these changes yielded a similarity of 69.4 and $78.6 \%$ between the Arctica islandica growth rate chronology and those of Mya truncata and Chamelea striatula, respectively. The similarity between $M$. truncata and C. striatula was $69 \%$.
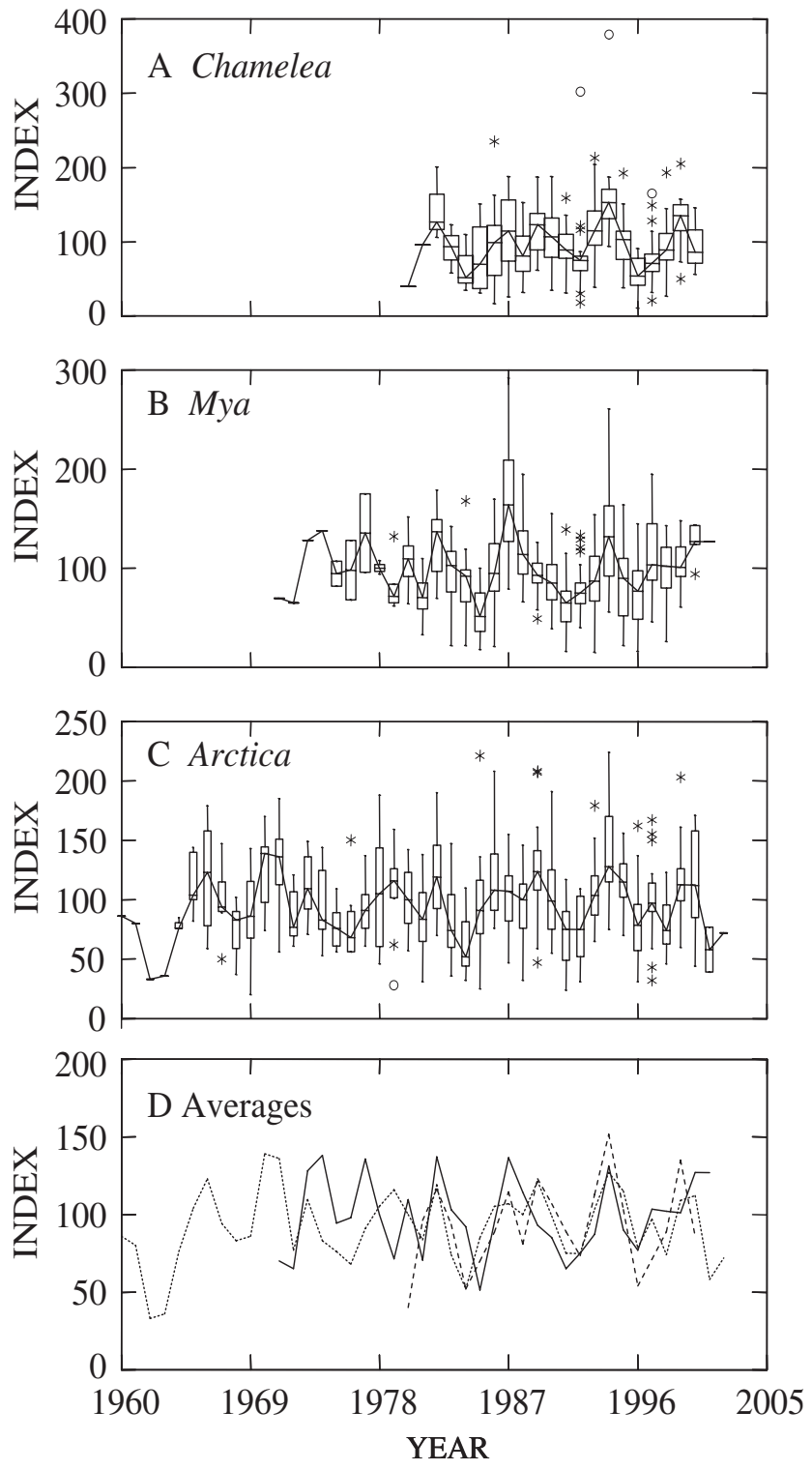

Fig. 3. Chamelea striatula, Mya truncata, Arctica islandica (A-C) Annual growth variations. Boxes represent the interquartile range (IQR), horizontal lines in boxes are medians, vertical lines are overall range; outliers: $*(1.5$ to $3 \mathrm{IQR}$ beyond the range), O (<3 IQR beyond the range). (D) Average curve for each species (broken line: C. striatula; continuous line: $M$. truncata, dotted line: A. islandica). Index values along the $y$-axis represent standardized growth 

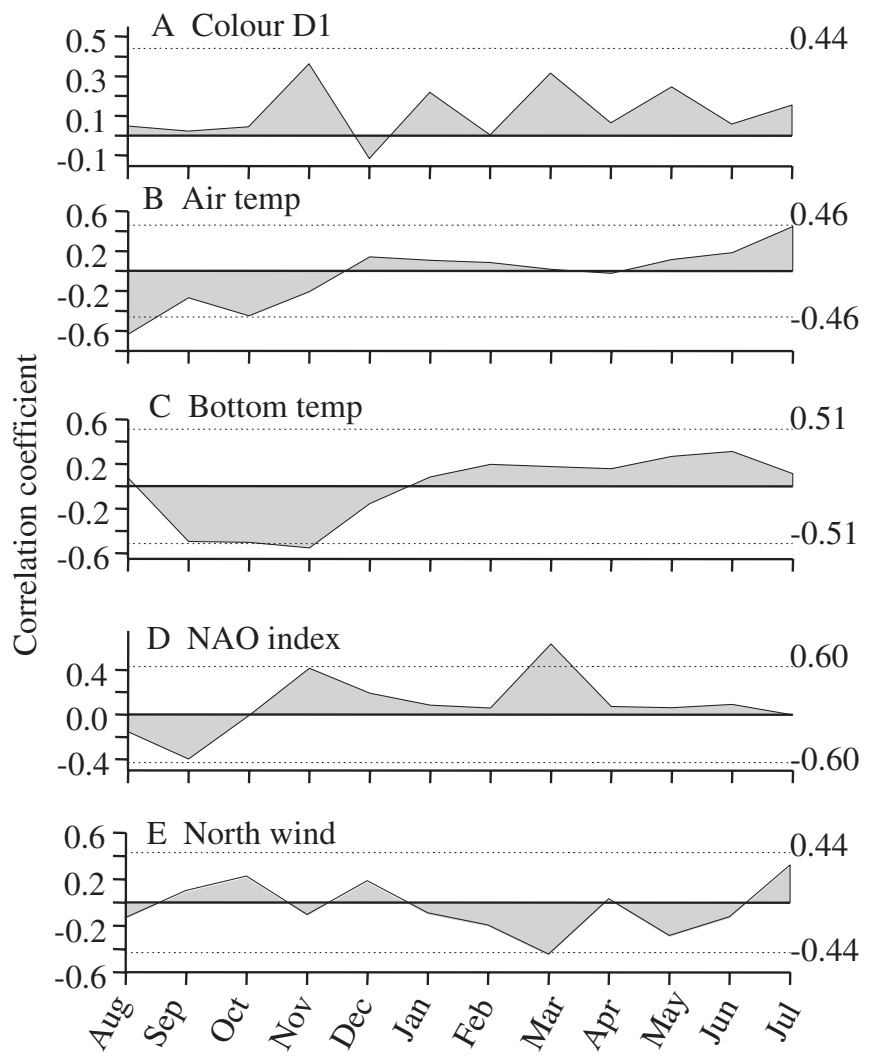

Fig. 4. Correllograms between the first principal component (PC1) derived from average annual shell growth (1980-2000) of the 3 bivalve species and monthly averages of (A) CPR phytocolour for standard area D1, (B) air temperature, (C) bottom water temperature, (D) the NAO index, and (E) the duration (h) of northerly winds $\left(315^{\circ}\right.$ to $\left.45^{\circ}\right)$. Dotted horizontal lines denote the $95 \%$ confidence levels

The common trend in the 3 species-specific chronologies was extracted by PCA and covers the period 1980 to 2000 . Before 1980 the data density was too low for analysis. The first principal component (PC1) over a given period, extracted from the average growth index series for each of the 3 species, explained $69 \%$ of the variance. PC2 explained an additional $20 \%$ of the variance.

\subsection{Shell growth and environmental factors}

PC1 extracted from the average growth index series of the 3 species was used in the further analyses to find an underlying factor and a possible mechanism which could explain their similarity in growth. The correlation and response function analyses using the CPR phytocolour data showed that monthly phytoplankton colour is positively correlated to shell growth, except in December, but none of the correlation coefficients was significant (Fig. 4A). We used 2 datasets to test for a significant correlation between shell growth and temperature: (1) Air temperatures measured at De Bilt (Netherlands) by the KNMI (www.knmi.nl/onderzk/), which serve as a proxy for surface seawater temperatures in this part of the North Sea (Roozenkrans 1999) as well as an index for the overall climate and weather in this area. (2) Bottom water temperatures estimated by the model of Pohlmann (1996) on the basis of sea surface temperatures (Fig. 4B,C). An inverse relationship initially exists between temperature and annual shell growth, suggesting that high temperatures between August and January depress shell growth. From January to early summer, higher temperatures tend to coincide with higher shell growth rates. The negative relationship between shell growth and air temperature in August of the year preceding increment termination is significant $(R=-0.64)$. The correlation coefficients for September to January are close to significant. The response function model constructed from the monthly air temperatures explains $63 \%$ of the variance in the growth rate time series.

Fig. 4D depicts the relationship between the shell growth index series and the monthly NAO index values. In autumn (October) the effect of the NAO becomes positive and becomes significant in March. The corresponding response function model also explains $63 \%$ of the variation in shell growth. The relationship between shell growth and the NAO index in March (Fig. 5) is significant ( $p=0.006)$. It is hard to conceive how the NAO index by itself can affect shell growth, but wind strength and direction are more likely to play a role by its effect on hydrography and wave climate. In our study area, northerly winds have

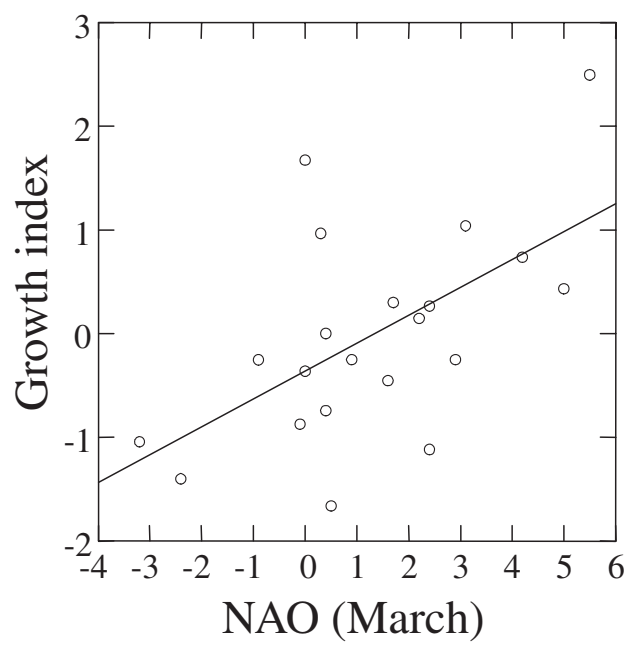

Fig. 5. Regression between PC1 derived from average annual shell growth of the 3 bivalve species and the NAO index in March. The regression is significant $(p=0.006 ; R=0.578)$ 

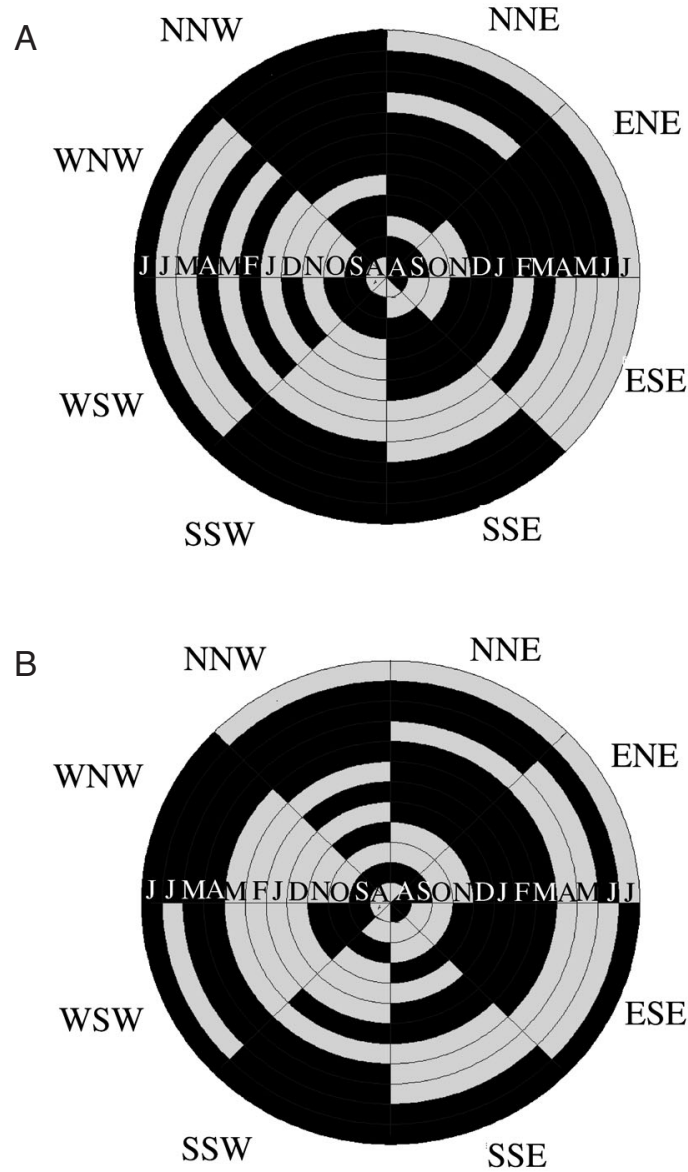

Fig. 6. Directograms of the relationship between monthly wind duration and PC1 derived from the average annual shell growth (1980-2000) of the 3 bivalve species. Period in the year is given along the axes and starting in the centre with August in the year before a growth band is terminated. Grey: positive relationship; black: negative relationship. (A) Directogram for the total duration of wind; the pattern is significant ( $p$ < 0.05). (B) Directogram for winds with a potential wind speed $>10 \mathrm{~m} \mathrm{~s}^{-1}$ (not significant)

the longest possible fetch and generate largest wave heights. Northerly winds associated to low NAO indices might therefore be the underlying factor responsible for variations in shell growth. Fig. 4E gives the correlation between duration of northerly winds and annual shell growth. In spring and early summer the effect of northerly winds tended to be negative.

The underlying cause of the observed variations in shell growth remains unclear, because temperature, wind and the NAO are intimately linked. While the effect of temperature could be direct, wind may have indirectly affected shell growth by the generation of waves and resuspension of sediments. Wind may thus have generated variations in annual growth of the 3 bivalve species over the study period. We tested the combined effect of wind and season by using data that were collected at the offshore platform K13. Hourly data on wind speed and direction were grouped into 8 sectors, each covering $45^{\circ}$ of the compass (WNW, NNW, NNE, ENE, ESE, SSE, SSW, and WSW). For each sector, we calculated the monthly sum of hours during which the wind came from a particular sector and correlated these monthly sums with the shell growth record. A second series of analyses was performed using the monthly duration of wind strong enough $\left(10 \mathrm{~m} \mathrm{~s}^{-1}\right)$ to generate currents that resuspend bottom sediment.

The combined effect of monthly wind direction on shell growth is depicted in Fig. 6A. Each concentric circle represents a month of the year, starting with August in the centre. The significance of the observed ordering (i.e. the pattern) of positive and negative relationships according to season and wind direction was tested by generating response matrices by bootstrapping. For each of the bootstrapped matrices the statistic derived from run tests on columns (seasons) and rows (wind directions) was summed. The frequency distribution of this value was used to estimate the chance of finding a pattern such as that observed in our study. This bootstrapping procedure showed that the probability of finding a pattern as depicted in Fig. $6 \mathrm{~A}$ was $<5 \%$, suggesting that the observed interaction between monthly wind direction and duration with shell growth is not random. Winds from a NW to easterly direction tended to depress growth, whereas winds with a westerly component tended to have a positive effect.

In Fig. 6B a similar scheme is shown for winds that resuspend the sediment. The pattern again suggests that the effects on shell growth vary seasonally, but the pattern was non-significant $(p>0.05)$ when tested as described above. The effects of strong winds were most evident for winds from a WNW direction. The response function model on the basis of WNW winds with speeds above $10 \mathrm{~m} \mathrm{~s}^{-1}$ could explain $80 \%$ of the variance in the time index series of shell growth. The analyses indicate that strong winds, especially in May, affect growth negatively. The variance explained by strong winds from other directions was on average $40 \%$ lower.

\section{DISCUSSION}

The analyses demonstrate that the common trend in shell growth of the 3 bivalve species is linked with climatic factors in the study area. Determining the contribution of the effect of each factor on the growth trend is hampered by the length of the common growth index series in view of the large number of possible combinations of factors and months. Moreover, a 
complex coupling exists between the separate factors. Winter air temperature in NW Europe is linked to the NAO index representing the air circulation pattern over the Atlantic. In positive NAO winters, strong westerly winds bring warm wet air to NW Europe, while in negative NAO winters low temperatures prevail and storm frequency is low (www.atmosphere. mpg.de/enid/1vs.html). Hence, a relationship between winter temperature and growth could be confounded by wind effects associated with the NAO index. Furthermore, effects of wind direction on shell growth can be confounded by the underlying seasonal coupling between wind direction and temperature. In winter, easterly winds in this part of the North Sea give rise to low temperatures, whereas in summer similar winds are associated with high temperatures. The reverse is true for westerly winds.

Temperature is the factor most likely to affect the metabolism and shell growth of bivalves, as demonstrated in laboratory experiments and field studies (e.g. Witbaard et al. 1997, 1999). Shell growth in the 3 bivalve species indeed tends to be positively correlated with bottom water temperature from early winter until the end of summer, but the correlation is weak (Fig. 4B,C). From the end of summer (August and September) through autumn, temperature shows a strong and negative effect on shell growth. In the case of Arctica islandica, the bottom water temperature at the end of summer may approach or even surpass its upper temperature limit (Lutz et al. 1982, Mann 1982) and hence could inhibit shell growth. A similar temperature effect may apply to the northern species Mya truncata. Furthermore, hypoxic conditions associated with high summer temperatures in the Oyster Grounds (de Wilde et al. 1984) could lead to a reduction of shell growth rates, because the animals become dormant (Abele 2002). The weak positive relation between growth and temperature in spring and summer, and the stronger negative relation with autumn and winter temperatures, are consistent with the results of Schöne et al. (2003, 2004), who found a significant negative correlation between winter air temperature and shell growth in $A$. islandica from the Dogger Bank (central North Sea). Schöne et al. (2004) showed that increment width in A. islandica shells from the Amrum Bank did not correlate with stable isotope derived temperatures in the main growing season (February to September). This strongly suggests that factors other than temperature are more important for in situ shell growth.

CPR phytocolour is a measure of phytoplankton standing stock and probable food availability in the (upper) water column. Despite the almost continuous positive correlation between CPR phytoplankton colour (standing stock) and shell growth in Fig. 4A, no significant coefficients were found. This suggests that either food production in the upper water layers has never been a limiting factor or that other factors overshadowed or modified the food supply to the seabed. It is possible that shell growth is determined more by the amount and quality of food particles close to the seabed than by the standing stock in the upper water column (Witbaard et al. 2003).

Witbaard et al. (2001) showed that shell growth of Arctica islandica and Chamelea striatula living in the fine sediments of the southern North Sea is slower than that of specimens from coarse sediments. Field measurements have demonstrated that regular resuspension of the fine sediment at the Frisian Front dilutes food concentrations and lowers food quality for suspension feeders (Duineveld \& Boon 2002). This may explain the depressed growth rates in fine-grained sediments, as is the case in other areas with frequent resuspension (Emerson 1990, Turner \& Miller 1991, Bock \& Miller 1994, Urrutia et al. 1996, Grant et al. 1997, Cranford et al. 1998, Gremare et al. 1998).

In the Oyster Grounds, with depths ranging between 30 and $50 \mathrm{~m}$, resuspension of fine sediment is mainly due to wave and current action in combination with tides (Jones et al. 1997). Wave activity depends on wind direction and strength. Our field observations in summer 2001 (Fig. 2) showed that a current speed of $0.25 \mathrm{~m} \mathrm{~s}^{-1}$ at $0.5 \mathrm{~m}$ above the seabed is required to start resuspension of the sediment. This is supported by an experimental study of Creutzberg \& Postma (1979). Comparison of the wind data with lander measurements suggests that this critical erosion velocity is exceeded at potential wind speeds of $10 \mathrm{~m} \mathrm{~s}^{-1}$ (Beaufort 6), which we used as the threshold value. This is to some extent arbitrary, because at spring tide a smaller contribution from the wind (waves) is required than at neap tides. Wave height would perhaps have been a better parameter to use instead of wind, because it can be directly translated into a contribution to near-bed shear velocity (Williams et al. 1998). Wave height data are, however, not available for our Frisian Front site.

The correlation analyses of shell growth, wind direction and season suggest that winds with a westerly component have a positive effect (Fig. 6A). Shell growth is mainly negatively affected by northerly to easterly winds (Fig. 6A). Especially at the start of the phytoplankton spring bloom, northerly winds tended to have negative effects on growth (Fig. 4E). Similar negative effects are found if strong winds from the WNW in May are considered (Fig. 6B). According to Dickson et al. (1988), northerly winds have a delaying effect on primary production and thus may affect food availability to the benthos, but we did not find a relationship between shell growth and the CPR phytocolour values (Fig. 4A). In the SE North Sea, north- 
westerly winds have a long enough fetch to generate long wave lengths in the Frisian Front area. These long waves make a relatively large contribution to the near bottom currents and thus to the resuspension of fine bottom material in the study area. Because spring is the main growing period for bivalves in this area, this wind-mediated resuspension is expected to depress shell growth.

The complex interrelationships demonstrate that effects of climate change on an ecosystem are only comprehensible if the mechanisms along which climate controls ecosystem functioning are clear. Our attempt to unravel the link between climate and the benthic ecosystem of the shallow SE North Sea suggests that effects of climate change might operate along pathways that are less direct than one would expect.

Acknowledgements. We thank the crew of RV 'Pelagia' for their help during the field work, and H. Franken for his assistance with deployment of the mooring. T.A. was funded by the Fundação para a Ciência e Tecnologia (Lisbon, Portugal) and the Fundo Social Europeu (FSE).

\section{LITERATURE CITED}

Abele D (2002) The radical life giver. Nature 420:27

Aebischer NJ, Coulson JC, Colebrook JM (1990) Parallel long-term trends across four marine trophic levels and weather. Nature 347:753-754

Amaro T, Duineveld G, Bergman M, Witbaard R (2003) Growth variations in the bivalve Mya truncata: a tool to trace changes in the Frisian Front macrofauna (southern North Sea)? Helgol Mar Res 57:132-138

Backeljau T, Bouchet P, Gofas S, De Bruyn L (1994) Genetic variation, systematics and distribution of the venerid clam Chamelea gallina. J Mar Biol Assoc UK 74:211-223

Beaugrand G, Brander KM, Lindley JA, Souissi S, Reid PC (2003) Plankton effect on cod recruitment in the North Sea. Nature 426:661-664

Bergman MJN, van Santbrink JW (1994) A new benthos dredge (Triple-D) for quantitative sampling of infauna species of low abundance. Neth J Sea Res 33:129-133

Beukema JJ, Cadée GC, Dekker R (2002) Zoobenthic biomass limited by phytoplankton abundance: evidence from parallel changes in two long-term data series in the Wadden Sea. J Sea Res 48:111-125

Bock JM, Miller DC (1994) Seston variability and daily growth in Mercenaria mercenaria on an intertidal sandflat. Mar Ecol Prog Ser 114:117-127

Brousseau DJ, Baglivo JA (1987) A comparative study of age and growth in Mya arenaria (soft-shell clam) from three populations in Long Island. J Shellfish Res 6:7-15

Corten A (2001) Northern distribution of North Sea herring as a response to high water temperatures and/or low food abundance. Fish Res 50:189-204

Cranford PJ, Emerson CW, Hargrave BT, Milligan TG (1998) In situ feeding and absorption responses of sea scallops Placopecten magellanicus (Gmelin) to storm induced changes in the quantity and composition of seston. J Exp Mar Biol Ecol 219:45-70
Creutzberg F (1985) A persistent chlorophyll a maximum coinciding with an enriched benthic zone. In: Gibbs PE (ed) Proc 19th Eur Mar Biol Symp, Plymouth, UK, 16-21 Sep 1984. Cambridge University Press, Cambridge, p 97-107

Creutzberg F, Postma H (1979) An experimental approach to the distribution of mud in the southern North Sea. Neth J Sea Res 13:99-116

Creutzberg F, Wapenaar P, Duineveld G, Lopez-Lopez N (1984) Distribution and density of the benthic fauna in the southern North Sea in relation to bottom characteristics and hydrographic conditions. Rapp P-V Reun Cons Int Explor Mer 183:101-110

Dekker R, Beukema JJ (1999) Relations of summer and winter temperatures with dynamics and growth of two bivalves Tellina tenuis and Abra tenuis on the northern edge of their intertidal distribution. J Sea Res 42:207-220

De Wilde PAWJ, Berghuis EM, Kok A (1984) Structure and energy demand of the benthic community of the Oyster Ground, central North Sea. Neth J Sea Res 18:143-159

Dickson RR, Kelly PM, Colebrook JM, Wooster WS, Cushing DH (1988) North winds and production in the eastern North Atlantic. J Plankton Res 10:151-169

Drinkwater KF, Belgrano A, Borja A, Conversi A and 5 others (2003) The response of marine ecosystems to climate variability associated with the North Atlantic Oscillation. In: Hurrell JW, Kushnir Y, Ottersen G, Visbeck M (eds) The North Atlantic Oscillation: climatic significance and environmental impact. Geophys Monogr 134:211-234

Duineveld GCA, Boon AR (2002) Short-term variations in the fluxes and composition of seston in near-bottom traps in the southern North Sea. Helgol Mar Res 56:140-148

Emerson CW (1990) Influence of sediment disturbance and water flow on the growth of the soft-shell clam Mya arenaria L. Can J Fish Aquat Sci 47:1655-1663

Fritts HC, Shashkin AV (1995) Modelling tree-ring structure as related to temperature, precipitation, and day length. In: Lewes TE (ed) Tree rings as indicators of ecosystem health. CRC Press, London, p 17-57

Fritts HC, Blasing TJ, Hayden BP, Kutzbach JE (1971) Multivariate techniques for specifing tree-growth and climate relationships and for reconstructing anomalies in paleoclimate. J Appl Meterol 10:845-864

Fritts HC, Vaganov EA, Sviderkaya IV, Sashkin AV (1991) Climatic variation and tree-ring structure in conifers: empirical and mechanistic models of tree-ring width number of cells cell size cell wall thickness and wood density. Climate Res 1:97-116

Fromentin JM, Planque B (1996) Calanus and environment in the eastern North Atlantic. II. Influence of the North Atlantic Oscillation on C. finmarchicus and C. helgolandicus. Mar Ecol Prog Ser 134:111-118

Grant J, Cranford P, Emerson C (1997) Sediment resuspension rates, organic matter quality and food utilization by sea scallops (Placopecten magellanicus) on Georges Bank. J Mar Res 55:965-994

Gremare A, Amouroux JM, Chaabeni Y, Charles F (1998) Experimental study of the effect of kaolinite on the ingestion and the absorption of monospecific suspensions of Pavlova lutheri by the filter-feeding bivalve Venus verrucosa. Vie Milieu 48:295-307

Grissino-Mayer HD (2001) Evaluating cross-dating accuracy: a manual and tutorial for the computer program COFECHA. Tree-Ring Res 57:205-221

Hagberg J, Tunberg BG (2000) Studies on the covariation between physical factors and the long-term variation of the marine soft bottom macrofauna in western Sweden. Estuar Coast Shelf Sci 50:373-385 
Holmes RL (1983) Computer-assisted quality control in treering dating and measurement. Tree-Ring Bull 43:69-78

Hurrell JW (1995) Decadal trends in the North Atlantic Oscillation: regional temperatures and precipitation. Science 269:676-679

Irigoien X, Harris RP, Head RN, Harbour D (2000) North Atlantic Oscillation and spring bloom phytoplankton composition in the English Channel. J Plankton Res 22: $2367-2371$

Jones DS (1980) Annual cycle of shell growth increment formation in two continental shelf bivalves and its paleoecologic significance. Palaeobiology 6:331-340

Jones DS (1983) Sclerochronology: reading the record of the molluscan shell. Am Sci 71:384-391

Jones SE, Jago CF, Bale AJ, Chapman D, Howland RJM, Jackson J (1997) Aggregation and resuspension of suspended particulate matter at a seasonally stratified site in the southern North Sea: physical and biological controls. Cont Shelf Res 18:1283-1309

Kröncke I, Dippner JW, Heyen H, Zeiss B (1998) Long-term changes in macrofaunal communities off Norderney (East Frisia, Germany) in relation to climate variability. Mar Ecol Prog Ser 167:25-36

Lutz RA, Mann R, Goodsell JG, Castagna M (1982) Larval and early postlarval development of Arctica islandica. J Mar Biol Assoc UK 62:745-769

MacDonald BA, Thomas MLH (1980) Age determination of the soft-shell clam Mya arenaria using shell internal growth lines. Mar Biol 58:105-109

Mann R (1982) The seasonal cycle of gonadal development in Arctica islandica from the southern New England shelf. Fish Bull 80:315-326

Ottersen G, Planque B, Belgrano A, Post E, Reid PC, Stenseth NC (2001) Ecological effects of the North Atlantic Oscillation. Oecologia 128:1-14

Pohlmann T (1996) Predicting the thermocline in a circulation model of the North Sea. Part I: Model description, calibration and verification. Cont Shelf Res 16:131-146

Ramon M, Richardson CA (1992) Age determination and shell growth of Chamelea gallina (Bivalvia: Veneridae) in the western Mediterranean. Mar Ecol Prog Ser 89:15-23

Reid PC, Edwards M, Hunt HG, Warner AJ (1998) Phytoplankton change in the North Atlantic. Nature 391:546

Reid PC, Holiday NP, Smyth TJ (2001) Pulses in the eastern margin current and warmer water off the northwest European shelf linked to North Sea ecosystem changes. Mar Ecol Prog Ser 215:283-287

Roozekrans JN (1999) A 10-year NOAA-AVHRR SST database of the North Sea. In: 1999 EUMETSAT Meteorological Satellite Data Users Conference, Copenhagen, Denmark, EUM P 26:657-662

Editorial responsibility: Otto Kinne,

Oldendorf/Luhe, Germany
Ropes JW (1985) Modern methods used to age oceanic bivalves. Nautilus 99:53-57

Schöne BR, Kröncke I, Houk SD, Freyre Castro AD, Oschmann W (2003) The cornucopia of chilly winters: ocean quahog (Arctica islandica L., Mollusca) master chronology reveals bottom water nutrient enrichment during colder winters (North Sea). Senckenb Marit 32:165-175

Schöne BR, Freyre Castro AD, Fiebig J, Houk SD, Oschmann W, Kröncke I (2004) Sea surface water temperatures over the period 1884-1983 reconstructed from oxygen isotope ratios of a bivalve mollusk shell (Arctica islandica, southern North Sea). Palaeogeogr Paleoclimatol Palaeoecol 212:215-232

Turner EJ, Miller DC (1991) Behaviour and growth of Mercenaria mercenaria during simulated storm events. Mar Biol 111:55-64

Urrutia MB, Iglesias JIP, Navarro E, Prou J (1996) Feeding and absorption in Cerastoderma edule under environmental conditions in the Bay of Marennes-Oleron (western France). J Mar Biol Assoc UK 76:431-450

Wieking G, Kröncke I (2001) Decadal changes in macrofauna communities on the Dogger Bank caused by large-scale climate variability. Senckenb Marit 31:125-141

Williams JJ, Humphrey JD, Hardcastle P, Wilson DJ (1998) Field observations of hydrodynamic conditions and suspended particulate matter in the southern North Sea. Contin Shelf Res 18:1215-1234

Witbaard R (1997) Tree of the sea: the use of internal growth lines in the shell of Arctica islandica (Bivalvia, Mollusca) for the retrospective assessment of marine environmental change. PhD thesis, University of Groningen and Netherlands Institute for Sea Research, Texel

Witbaard R, Bergman M (2003) The distribution of Arctica islandica in the North Sea: what possible factors are involved? J Sea Res 50:11-25

Witbaard R, Jenness MI, van der Borg K, Ganssen G (1994) Verification of annual growth increments in Arctica islandica L. from the North Sea by means of oxygen and carbon isotopes. Neth J Sea Res 33:91-101

Witbaard R, Franken R, Visser B (1997) Growth of juvenile Arctica islandica under experimental conditions. Helgol Meeresunters 51:417-431

Witbaard R, Duineveld GCA, de Wilde PAWJ (1999) Geographic differences in growth rates of Arctica islandica (Mollusca: Bivalvia) from the North Sea and adjacent waters. J Mar Biol Assoc UK: 79 907-915

Witbaard R, Duineveld GCA, Bergman M (2001) The effect of tidal resuspension on benthic food quality in the southern North Sea. Senckenb Marit 31:225-234

Witbaard R, Jansma E, Sass-Klaassen U (2003) Copepods link quahog growth to climate. J Sea Res 50:77-83

Submitted: March 17, 2005; Accepted: November 4, 2005 Proofs received from author(s): November 25, 2005 